\title{
Geneza, właściwości i klasyfikacja czarnych ziem w Polsce
}

\begin{abstract}
Streszczenie. Czarne ziemie, w randze osobnej jednostki, wyodrębnione zostały przez Miklaszewskiego ze względu na ich pobagienną genezę, podmokłość oraz specyficzny typ „kwaśnej” próchnicy. Z czasem zaczęto określać tym mianem także inne podmokłe gleby z głębokim poziomem próchnicznym o różnej genezie: (1) czarne ziemie pojeziorne (pobagienne), (2) czarne ziemie błotne (z przeobrażenia gleb torfowo- i torfiasto-glejowych), (3) czarne ziemie deluwialne, (4) czarne ziemie ukształtowane w procesie wertylizacji, (5) czarne ziemie powstałe w efekcie zwiększenia wilgotności czarnoziemów łąkowo-leśnych, (6) poligenetyczne czarne ziemie z poziomem iluwiacji iłu. Klasyfikacja gleb o tak zróżnicowanej genezie musi opierać się na wspólnych kryteriach morfologicznych, to jest zgodnie z trendem wyznaczonym przez systematyki gleb Polski z lat 1989 i 2011. Jednak przynależność do czarnych ziem nie zawsze jest jednoznaczna, ze względu na nieprecyzyjne rozgraniczenie w punktach stycznych z pokrewnymi glebami, w tym z czarnoziemami (intensywność oglejenia), madami i glebami deluwialnymi (stratyfikacja materiału macierzystego i/lub poziomu mollic), vertisolami (obecność poziomów mollic i vertic) oraz glebami murszastymi (brak różnic w kryteriach diagnostycznych). Ponadto, uzupełnienia wymagają charakterystyki czarnych ziem pod kątem rodzaju oglejenia (gruntowego oraz opadowego), rodzaju węglanów (wtórnych i pierwotnych) oraz obecności poziomu diagnostycznego anthric.
\end{abstract}

Stowa kluczowe: czarne ziemie, czarnoziemy, mady czarnoziemne, gleby deluwialne, vertisole

\section{WSTĘP}

Gleby czarnoziemne, w tym głównie czarne ziemie, zajmują w Polsce tylko nieco ponad 3\% ogólnej powierzchni kraju, ale wśród rolników i gleboznawców są przedmiotem szczególnego zainteresowania, ze względu na wysoką żyzność. Wspólną cechą gleb czarnoziemnych jest głęboki, ciemno zabarwiony poziom próchniczny zasobny w materię organiczna, ale różnice $\mathrm{w}$ genezie, morfologii i właściwościach fizykochemicznych w przeszłości uzasadniały zaliczanie ich nie tylko do osobnych typów, ale nawet rzędów/działów. W obowiązującej Systematyce gleb Polski (SgP) 2011, wszystkie gleby z poziomem diagnostycznym mollic, umbric i murshic zostały zebrane w jednym rzędzie, co jednak nie oznacza rezygnacji z podkreślania ich odrębności.

Watpliwości, dotyczące nieczarnoziemowej genezy „gleb próchnicowych" z wybitnie hydromorficznymi cechami, zainspirowały Miklaszewskiego (1930) do wyodrębnienia w Polsce typu czarnych ziem (pobagiennych). $Z$ upływem czasu, do czarnych ziem zaczęto zaliczać różnorodne gleby semihydrogeniczne, którym nie można było przypisać genezy pobagiennej, w następstwie czego narastały wątpliwości co do przyrodniczej i użytkowej identyfikacji tych gleb w ramach jednego typu. Tym bardziej, że do czarnych ziem zalicza się gleby o zróżnicowanym uziarnieniu, właściwościach fizykochemicznych i mające dodatkowe poziomy charakterystyczne dla innych typów gleb. W najnowszej SgP (2011) właściwie zrezygnowano $\mathrm{z}$ omówienia genezy czarnych ziem i wzmocniono ich klasyfikację w oparciu o rozpoznanie poziomów i właściwości diagnostycznych, co tylko do pewnego stopnia umożliwia zrozumienie odrębności tych gleb od innych typów w rzędzie gleb czarnoziemnych.

Celem pracy jest analiza poglądów na genezę czarnych ziem, w kontekście ich definicji i kryteriów diagnostycznych, a także analiza spójności klasyfikacji czarnych ziem w ramach rzędu gleb czarnoziemnych w Systematyce gleb Polski.

\section{ODRĘBNOŚĆ GENEZY CZARNOZIEMÓW I CZARNYCH ZIEM}

Najstarsze holoceńskie czarnoziemy zaczęły się kształtować w ocieplającym się klimacie okresu preborealnego i borealnego, głównie na zasobnych w węglany podłożach lessowych południowo-wschodniej Europy, opanowanych wówczas przez formacje roślinności stepowej (Altermann et al. 2005). Początkowo, wielu uczonych było przekonanych o występowaniu stepu we wczesnym holocenie również w 
środkowej Europie (Stremme 1930), ale między innymi za sprawą Firbasa (1949) zaczęto akcentować rolę lasostepu (Altermann et al. 2005). W późniejszym okresie pojawily się alternatywne koncepcje (Albrecht i Kühn 2011; Dreibrodt et al. 2007; Turski 1980), w tym kontrowersyjna teoria o popożarowym (antropogenicznym) pochodzeniu czarnoziemów środkowoeuropejskich (Eckmeier et al. 2007). Polscy gleboznawcy zaakceptowali teorię czarnoziemu Dokuczajewa z zastrzeżeniem, że na terenie Polski prawdopodobnie nie występują czarnoziemy właściwe, lecz ich odmiany zdegradowane (Borowiec 1965; Miklaszewski 1930; Musierowicz 1953) rozwijające się w klimacie bardziej wilgotnym, sprzyjającym rozwojowi lasostepu lub formacji łąkowych (Dobrzański i Zbysław 1955). Opinie te opierały się m.in. na pracach Szafera (1959), według którego typowe formacje roślinności stepowej nie występowały w holocenie na obszarze Polski.

Pierwsza powojenna przyrodniczo-genetyczna klasyfikacja gleb Polski (1956) wiązała genezę czarnoziemów wyłącznie z klimatem kontynentalnym i stepową roślinnością. W trzecim wydaniu Systematyki gleb Polski (1974) podkreślono genetyczną różnorodność czarnoziemów polskich, wyróżniając dwa ich typy: czarnoziemy leśno-stepowe i leśno-łąkowe. Pierwsze tworzyły się w warunkach klimatu umiarkowanie kontynentalnego, wyłącznie na utworach lessowych zasobnych w węglany, pod wpływem roślinności łąkowo-stepowej lub leśno-stepowej. Możliwość występowania tych gleb w Polsce ograniczono do południowo-wschodnich rejonów kraju. $Z$ kolei do czarnoziemów leśno-łąkowych zaliczono gleby wytworzone $\mathrm{z}$ glin zwałowych, iłów i utworów pyłowych różnej genezy, z reguły zasobnych w węglany, powstałe w warunkach klimatu wilgotniejszego niż kontynentalny i przez to przeważnie oglejone (Musierowicz 1959). Trudności w praktycznym rozróżnianiu genetycznie zdefiniowanych dwóch typów czarnoziemów spowodowały, że w czwartym wydaniu Systematyki gleb Polski (1989) powrócono do jednego typu czarnoziemów, wytworzonych w warunkach stepowych i leśno-stepowych, natomiast wszystkie gleby z głębokim poziomem próchnicznym oraz silnymi cechami hydromorficznymi włączono do czarnych ziem. Obecnie obowiązująca systematyka (SgP 2011) wiąże genezę czarnoziemów z akumulacją materii organicznej w lessach i utworach pyłowych innego pochodzenia, zachodzącą $\mathrm{w}$ warunkach klimatu kontynentalnego, na obszarach zdominowanych przez roślinność trawiastą lub leśno-stepową. Cechami diagnostycznymi czarnoziemów są: głęboki i niemal czarny poziom próchniczny - mający trwałą strukturę gruzełkową (mollic), płytkie występowanie nagro- madzeń wtórnych węglanów lub poziomu calcic oraz brak (lub niewielkie nasilenie) cech hydromorficznych.

Nazwę czarne ziemie wprowadził do systematyki Miklaszewski (1930), który akcentując stepową genezę czarnoziemów, czarnymi ziemiami nazwał gleby pobagienne, powstające na podmokłych obszarach zanikających jezior i płytkich torfowisk $\mathrm{z}$ osadów w dużej mierze organicznych. Czarne ziemie takiego pochodzenia występują lokalnie w pojeziernych obniżeniach terenu, gdzie stale utrzymuje się wysoki poziom wód gruntowych lub okresowe podtopienie. Nadmierne uwilgotnienie gleby, stymulujące warunki beztlenowe, jest czynnikiem hamującym mineralizację materii organicznej i podtrzymującym jej „torfiasty" charakter, dlatego próchnicę czarnych ziem Miklaszewski (1930) nazywał „kwaśną”, w odróżnieniu od próchnicy „słodkiej” czarnoziemów.

Miklaszewski (1930) zauważył, że obok niewątpliwie pobagiennych czarnych ziem jest cała gama „gleb próchnicowych" o cechach pośrednich. Na obszarze Kujaw, oprócz „normalnych” czarnych ziem, opisywał silnie oglejone gleby położone na obszarze wysoczyznowym, które z całą pewnością nie miały genezy pobagiennej. Wbrew własnej oryginalnej definicji zaliczył jednak wszystkie te gleby do czarnych ziem, uznając, że większym błędem byłoby nazywanie ich czarnoziemami. Również Mieczyński (1947) i Musierowicz (1953) stosowali rozszerzoną definicję czarnych ziem, włączając do nich nie tylko gleby jednoznacznie pobagienne, ale też inne próchniczne gleby z silnymi cechami hydromorficznymi. Kowaliński (1952) oraz Uggla i Witek (1958) akcentowali, że częściej od czarnych ziem pobagiennych występują czarne ziemie „błotne”, powstałe przez przeobrażenie gleb próchniczno-glejowych użytkowanych przeważnie jako gleby ląkowe.

Na sposób definiowania czarnych ziem w Polsce, a przede wszystkim na ich powszechne wyróżnienie we wszystkich regionach kraju, decydujący wpływ miał, jak się dziś wydaje, uproszczony podział typologiczny gleb, stworzony na potrzeby powszechnej klasyfikacji bonitacyjnej użytków rolnych (Rozporządzenie 1957). W praktyce klasyfikacyjnej zaczęto stosować schematyczna - w istocie morfologiczna, a nie genetyczną- definicję czarnych ziem jako mineralnych, oglejonych gleb z głębokim poziomem próchnicznym (ponad $30 \mathrm{~cm}$ ), które ze względu na materiał macierzysty, położenie w krajobrazie i inne przesłanki nie zostały zaliczone do czarnoziemów lub mad (Strzemski et al. 1973). Spowodowało to niemal automatyczne wyróżnianie czarnych ziem na podstawie dwóch cech morfologicznych: (1) głębokiego, czarnego poziomu próchnicznego oraz (2) oglejenia/ podmokłości profilu glebowego. 


\section{RÓŻNORODNOŚĆ GENEZY GLEB IDENTYFIKOWANYCH JAKO CZARNE ZIEMIE}

\section{Czarne ziemie pojeziorne (pobagienne)}

"Cepuchy” kujawskie, gleby położone w miejscu i w otoczeniu zanikających jeziorek, mające gliniaste lub ilaste uziarnienie oraz smolisto czarną barwę poziomu próchnicznego $\mathrm{z}$ wyraźnymi cechami storfienia humusu powstały w efekcie prowadzonych od średniowiecza regulacji systemów rzecznych i jeziornych oraz melioracji odwadniających powodujących lokalne lub wielkoobszarowe obniżenie poziomu wód gruntowych, a także obniżenie zwierciadła wody w jeziorach i ciekach, niekiedy do całkowitego ich zaniku (Strzemski 1961). Strzemski (1954) stwierdził wprost, że obecność czarnych ziem może być wskaźnikiem odwodnienia terenu, na którym wcześniej ich miejsce zajmowały mokradła.

Zdaniem Cieśli $(1961,1968)$ najniżej położone czarne ziemie kujawskie powstały w wyniku prowadzonych od XVIII wieku prac melioracyjnych w dorzeczu Noteci, które spowodowały obniżenie poziomu wód Gopła i sąsiednich jezior oraz zmianę stosunków wodnych na obszarach przyległych. Borowiec (1960) przytacza przykład współczesnego powstawania niektórych czarnych ziem pyrzyckich. Już w średniowieczu cystersi zbudowali zastawy młyńskie na rzece Płoni, które podniosły poziom wód w jeziorach Płone i Miedwie o 1-2 metry, doprowadzając do zalania terenów otaczających jeziora. Usunięcie zastaw pod koniec XVIII wieku przywróciło poprzedni poziom wód i odsłoniło silnie humusowe osady jeziorne, które w krótkim czasie przeobraziły się w „,czarne ziemie" piaszczyste lub gliniasto-margliste. Poziom próchniczny pojeziornych czarnych ziem pyrzyckich ma zabarwienie smolisto-czarne, jest mazisty przy dużym uwilgotnieniu i posiada widoczne plamy oksydoredukcyjne wywołane okresowymi warunkami beztlenowymi (Borowiec 1961, 1962). Z kolei w Polsce północno-wschodniej pojeziorne czarne ziemie, o gliniasto-ilastym uziarnieniu i z odciskami otwornic oraz skorupek mięczaków, zostały opisane przez Ugglę (1957) oraz Ugglę i Witka (1958). Pobagienną (pojeziorna) genezę mogą mieć niektóre czarne ziemie scharakteryzowane przez Goneta et al. (2010) oraz Mendyka i Markiewicza (2013). Powstały z mineralnych i mineralno-organicznych, niekiedy silnie węglanowych osadów dennych lub mieszanych osadów strefy brzegowej jezior, zanikających wskutek drastycznego obniżenia zwierciadła wody. Występowanie typowo pojeziornych czarnych ziem na Równinie Błońsko-Sochaczewskiej nie jest pewne, choć
Wierszyłowski i Kotar (1947) oraz Musierowicz et al. (1956) wśród czarnych ziem glejowych tego rejonu wyróżnili tzw. cepuchy o wybitnie zwięźlejszym uziarnieniu i torfiastej próchnicy.

Osobny przypadek stanowia gleby wytworzone na podłożu węglanowej gytii lub kredy jeziornej. W ostatniej fazie osuszania jeziora, powierzchnię osadów węglanowych zaściela kożuch pływających dotąd roślin wodnych, dając zaczątek warstwie najpierw torfowej, a potem murszowej (Meller 2006). Jeśli warstwa ta uległa zamuleniu frakcjami mineralnymi może obecnie spełniać kryteria poziomu mollic $\mathrm{z}$ podwyższoną zawartością materii organicznej, niemal czarną barwa, agregatową strukturą oraz domieszką węglanów (Meller et al. 2009). Poziom próchniczny tych gleb, miąższości od 25 do $35 \mathrm{~cm}$, zawsze ostro odcina się od podłoża węglanowego. Mimo odwodnienia, gleby te okresowo są silnie podmokłe.

Kluczowym kryterium diagnostycznym przy ustaleniu pojeziornej genezy czarnych ziem, oprócz ich występowania w dawnych misach jeziornych lub na obrzeżach zanikających jezior, jest obecność w profilu warstw osadów limnicznych, przeważnie węglanowych lub ich reliktów w postaci rozproszonych grudek materiału węglanowego i skorupek mięczaków (Lemkowska i Sowiński 2008). Limniczne węglany mają charakter ,pierwotny”, czyli powstały na drodze sedymentacji w środowisku wodnym, a nie wskutek pedogenezy. W tym kontekście należy zwrócić uwagę, że SgP (2011) uwzględnia w czarnych ziemiach wyłącznie wtórne węglany (oznaczone symbolem k), co stwarza wrażenie, że ,archetypowe" czarne ziemie z dużą zawartością limnicznych węglanów pierwotnych (Miklaszewski 1930), nie należą do tego typu.

\section{Czarne ziemie błotne lub bagienno-błotne}

Rozróżnianie procesów oraz gleb bagiennych i błotnych, dziś już nieco zaniechane, w przeszłości było jedną z osi dyskusji nad systematyką gleb Polski (Tomaszewski 1954). Proces błotny, utożsamiany jest $\mathrm{z}$ akumulacją materii organicznej $\mathrm{w}$ warunkach stałego lub okresowego podtapiania lub zalewania, często z wytworzeniem płytkiej warstwy mułowej lub torfowej (Tomaszewski 1956). Błota i obszary grząskie, znajdujące się zarówno w zasięgu wód przepływowych, jak i w nieckach nieprzepływowych, zarosłe kępami roślinności hydrofilnej, z przynajmniej okresowo stagnująca woda, pokrywały w przeszłości duże obszary Polski (Strzemski 1961). Pierwotne gleby błotne można utożsamiać z różnymi wariantami gleb glejowych (rzadziej stagnoglejowych) powstałych z dużym udziałem substratu aluwialnego lub 
deluwialnego, przeważnie w podtypach torfowych, torfiastych i murszowych. Choć autorzy nie zawsze wprost to podaja, z charakterystyk terenowych wynika, że większość czarnych ziem błotnych wyróżniono na holoceńskich terasach zalewowych (niższych - zalewanych regularnie lub wyższych - zalewanych tylko incydentalnie).

Czarne ziemie, tworzące się z przeobrażenia ,błotnoziemów" opisane zostały m.in. przez Prusinkiewicza i Kowalkowskiego (1964) w Puszczy Białowieskiej. Zajmują tam obrzeża płaskich obniżeń przepływowych, w dnie których nadal występują podmokłe ,,błotnoziemy”. Czarne ziemie Puszczy Białowieskiej są wilgotnymi glebami leśnymi (zbiorowisko łęgu Circaeo-Alnetum z elementami Querco-Carpinetum) z czarnym, gruzełkowatym poziomem próchnicznym o miąższości 30-40cm, którego dolna część oraz poziomy niżej leżące są oglejone. W regionie podlaskim również Czerepko (2010) odnotował transformację składu olsu jesionowego wskutek przeprowadzonych zabiegów hydromelioracyjnych i przeobrażania się gleb błotnych w czarne ziemie. Asocjacje gleb glejowych i czarnych ziem opisane zostały w rezerwacie Żądłowice (Patalan et al. 2007) położonym na skraju wyższej terasy zalewowej Pilicy (woj. łódzkie). W skomplikowanym układzie „wyniesień" rozdzielonych płytkimi „dolinkami”, stale lub okresowo napełnionymi woda, można zidentyfikować mozaikę mineralnych gleb glejowych, średnio głębokich gleb torfowych i murszowych oraz czarnych ziem na ich obrzeżach. Ich cechą charakterystyczną jest torfiasta lub murszowata materia organiczna w poziomie próchnicznym. Obserwacje z uroczyska Żądłowice pokazuja, że precyzyjne rozróżnianie procesów bagiennych i błotnych nie zawsze jest możliwe. Zatem w reliefie pociętym licznymi rynnami lub nieckami dawnych starorzeczy mogą obok siebie występować czarne ziemie powstałe z przeobrażenia gleb błotnych (torfowo- lub murszowo-glejowych) oraz bagiennych (zamulonych gleb torfowych i murszowych).

Wielki program melioracji odwadniajacych zrealizowano na przełomie XIX i XX wieku w Kotlinie Sandomierskiej. Do tego czasu znaczne obszary pokrywały błota i mokradła, a regularne wezbrania rzek i mniejszych cieków powodowały wielomiesięczne stagnowanie wody na polach i łąkach (Klimowicz 1980). Zdaniem Klimowicza (1980) czarne ziemie powstałe $\mathrm{z}$ gleb błotnych (a właściwie wytworzone wskutek odwodnienia terenu i użytkowania ornego) są glebami młodymi, gdyż ich obecny profil ukształtowany został w czasach historycznych lub nawet współczesnych. Prawdopodobnie w podobny sposób powstały niektóre czarne ziemie w okolicach Błonia,
Sochaczewa i Lowicza (Borek 1975), o których to terenach Miklaszewski (1930) pisał, że ,,były w przeszłości błotami porośniętymi przeważnie olszyną”. Również piaszczyste czarne i szare ziemie w Puszczy Kampinoskiej (Konecka-Betley et al. 1996), w Pradolinie Głogowsko-Milickiej (Bogacz et al. 2008) a także na staroaluwialnych fragmentach Roztocza (Uziak et al. 2010) oraz w dolinie Bugu (Borowiec et al. 2007) sa glebami powstałymi przez wielkoskalowe odwodnienie „,błot”, głębokie zaoranie warstwy powierzchniowej i stopniowe przeobrażenie materii organicznej, dość długo zachowującej swój pierwotny torfiasty charakter (Labaz et al. 2011). W podsumowaniu badań nad czarnymi ziemiami wrocławskimi Kowaliński (1952) wnioskuje, że punktem wyjścia dla ich powstawania, szczególnie na obrzeżach dolinek rzecznych, były gleby łąkowo-błotne i błotne, ale nietorfowe i nieleśne.

Identyfikacja niektórych czarnych ziem błotnych (i bagienno-błotnych) w SgP (2011) jest problematyczna, wskutek nieprecyzyjnego rozgraniczenia $\mathrm{z}$ madami próchnicznymi, należącymi do tego samego rzędu. W niektórych glebach aluwialnych z poziomem mollic lub umbric, nawet tych położonych na holoceńskich terasach zalewowych, warstwowanie substratu fluwialnego może być słabo widoczne lub zaznaczone tylko w dolnej części profilu, poniżej zwierciadła wody gruntowej (Kabała et al. 2011). Nie jest wtedy jasne, czy o zaliczeniu do czarnych ziem lub mad czarnoziemnych mają decydować określone cechy morfologiczne profilu glebowego, czy tylko położenie profilu na zalewanej lub niezalewanej terasie rzecznej.

\section{Czarne ziemie deluwialne}

Czarne ziemie, których ciemny poziom próchniczny został przynajmniej w części nadbudowany przez procesy lokalnej akumulacji podstokowej, opisane zostały we wszystkich regionach Polski (Borkowski 1964; Kowaliński 1952; Kowalkowski 1966; Krysiak i Tołoczko 2004; Malinowska i Ceglińska 2011, Malinowski et al. 2013; Stasik i Szafrański 2005; Uziak et al. 2010). Gleby te mają bardzo zróżnicowane uziarnienie i właściwości fizykochemiczne, zależne od charakteru gleb erodowanych oraz od składu zasilających wód. Podstawowymi kryteriami wyróżniania tych gleb, jak wynika z opublikowanych charakterystyk, były: położenie w miejscu umożliwiającym akumulację osadów, obecność ciemnego poziomu próchnicznego o znacznej miąższości oraz oglejenie warstw podpowierzchniowych. Gdy miąższość poziomu próchnicznego przekraczała 50-60 cm, określano je przymiotnikiem ,akumulacyjne” (Marcinek i Wiślań- 
ska 1984) lub „kumulacyjne” (Marcinek i Komisarek 2004).

Czarne ziemie, w wielu płytkich obniżeniach między wyniosłościami, zajętymi głównie przez użytkowane rolniczo gleby płowe na falistych równinach morenowych całego Niżu Polskiego, należy zaliczyć do gleb o genezie przynajmniej w części deluwialnej (Borkowski 1964). Gleby te, poniżej czarnego poziomu mollic, często mają poziom iluwialnej akumulacji iłu Bt lub przewarstwienia o drobniejszym uziarnieniu, które zatrzymują w górnej części profilu wodę z opadów i roztopów. Okresowe (niekiedy długotrwałe) warunki redukcyjne konserwują namytą materię organiczną i przyczyniają się do utrwalenia czarnej barwy poziomu próchnicznego (Kowaliński 1952; Kowalkowski 1966). W genezie tych gleb współdziałają zatem dwa czynniki: deluwialne nadbudowywanie poziomu próchnicznego oraz osłabiona mineralizacja materii organicznej, w warunkach stagnowania wody. Niezależnie, w glebach tych może okresowo występować wysokie zwierciadło wód gruntowych, powodujące gruntowe oglejenie dolnej części profilu czarnej ziemi (Marcinek i Komisarek 2004). W przypadku braku poziomu argic oraz głębszego zalegania warstw trudno przepuszczalnych, w profilu może występować tylko oglejenie gruntowe. W każdym z wymienionych wariantów pobagienna geneza czarnych ziem jest na ogół wykluczana (Marcinek i Wiślańska 1984).

Dopóki głęboka orka homogenizuje cały poziom próchniczny, deluwialny charakter czarnych ziem w zagłębieniach i dolnych partiach stoków nie jest akcentowany. Jednak w poziomach próchnicznych o miąższości przekraczającej $30 \mathrm{~cm}$ (jak w czarnych ziemiach kumulacyjnych) może ujawnić się niejednorodność uziarnienia lub zawartości materii organicznej, typowa dla gleb deluwialnych. Jest więc niezwykle istotne, by jak najbardziej jednoznaczne były kryteria identyfikacji gleb deluwialnych próchnicznych w SgP (2011), a w szczególności by w pełni rozłączne były morfologiczne kryteria odróżniania tych gleb od czarnych ziem kumulacyjnych (a także czarnych ziem wyługowanych).

\section{Czarne ziemie z podpowierzchniową akumulacją iłu koloidalnego}

O ile obecność poziomu brunatnienia (cambic) pod poziomem próchnicznym w czarnych ziemiach nie wzbudza kontrowersji i jest jednoznacznie interpretowana jako przejaw postępującego przesuszenia i degradacji czarnej ziemi (Chojnicki 1994, 1997; Kozłowski i Komisarek 2013; Marcinek i Komisarek 2004), to obecność poziomu iluwiacji iłu pozostawia- na jest bez próby wyjaśnienia jego genezy. Tymczasem, uznawana obecnie koncepcja procesu płowienia wyklucza selektywna dyspersję i wymywanie iłu ze strukturalnego poziomu humusowego, zasobnego w próchnicę i nasyconego kationami zasadowymi, szczególnie wapniowymi (Driessen et al. 2000). Jedynym logicznym wythumaczeniem istnienia poziomu argic pod poziomem mollic jest powstanie tego pierwszego zanim wytworzył się poziom mollic. Takie sekwencje poziomów iluwialnych i próchnicznych (czarnoziemnych) w poligenetycznych glebach kopalnych są powszechnie znane i mają kluczowe znaczenie dla rekonstrukcji zmian klimatycznych i ekologicznych (Jary i Ciszek 2013; Konecka-Betley 2013).

Albrecht i Kühn (2011) podjęli próbę rekonstrukcji genezy podobnych gleb na wyspie Poel (Niemcy). Zgodnie z SgP (2011) gleby te zostałyby zaliczone do czarnych ziem z poziomem argic (z oglejeniem opadowym i wtórnymi węglanami w dolnej części profilu). Autorzy konkluduja, że w pierwszej fazie holocenu (aż po okres atlantycki) wytworzyły się jako gleby płowe, po uprzednim wyługowaniu węglanów z powierzchniowych warstw osadów. Wytworzenie się trudno przepuszczalnego poziomu Bt spowodowało stagnowanie wód opadowych, co w wilgotniejszym okresie subatlantyckim sprzyjało akumulacji materii organicznej. Podobne czarne ziemie z podpowierzchniowym poziomem iluwialnym (prawdopodobnie na ogół spełniającym kryteria poziomu argic) występuja powszechnie na terytorium Polski, m.in. na Równinie Kościańskiej i Pojezierzu Poznańskim (Cierniewski 1986; Komisarek 1994, 2000; Marcinek i Komisarek 2004; Staszewski 1967), na Wysoczyźnie Kaliskiej (Drzymała 1974; Michałek 1971), na Kujawach (Cieśla 1968; Olszewski et al. 1962), na Wzgórzach Dalkowskich (Kowalkowski 1966), na Równinie Wrocławskiej (Borkowski 1964; Kowaliński 1952). Jest wielce prawdopodobne, że podobnie jak czarne ziemie na wyspie Poel, są to gleby poligenetyczne, w których głęboki poziom próchniczny wytworzył się dopiero w okresie poatlantyckim, już po ukształtowaniu poziomu Bt.

\section{Czarne ziemie a czarnoziemy leśno-łąkowe}

Systematyka gleb Polski $(1989,2011)$ zrezygnowała z wyróżniania czarnoziemów leśno-łąkowych, co jednak nie oznacza zaprzeczenia możliwości ich powstawania i występowania na terytorium Polski. Podstawowymi warunkami tworzenia się czarnoziemnego poziomu próchnicznego są: (1) średnioprzepuszczalna skała macierzysta nasycona kationami zasadowymi lub zawierająca węglany, (2) roślinność trawiasta lub trawiasto-bylinowa $\mathrm{z}$ intensywnym syste- 
mem korzeniowym oraz odznaczająca się wysoką produktywnością biomasy nadziemnej oraz (3) duża aktywność dżdżownic oraz ssaków ryjących, mieszających i pogłębiających poziom próchniczny. Warunki te spełnia nie tylko step kontynentalny (suchy lub umiarkowanie suchy) i formacja leśno-stepowa, ale też formacja leśno-łąkowa klimatu umiarkowanie wilgotnego, pod warunkiem istnienia czynnika zmniejszającego zagęszczenie drzewostanu, co jest konieczne nie tylko dla wykształcenia się zbiorowisk trawiastych, ale też dla występowania ryjących ssaków glebowych, nietolerujących nadmiernego zagęszczenia korzeni drzew (Alexandrovskiy 2007).

Kluczowym czynnikiem mogły być zmiany w ekosystemach, spowodowane przez człowieka. Już we wczesnym neolicie (koniec okresu atlantyckiego początek subborealnego) wylesione zostały znaczne obszary środkowej Europy, a powstałe otwarte przestrzenie były użytkowane jako grunty orne (początkowo jedynie na niewielkich powierzchniach wokół osad) lub tereny wypasowe (Kulczycka-Leciejewiczowa 1993). Formacja luźnego „lasu wypasowego” umożliwia panowanie roślinności trawiastej (Bakker et al. 2004) i nie hamuje aktywności zwierząt ryjących, a więc sprzyja procesowi darniowemu i pogłębianiu poziomu próchnicznego. Zwarte osadnictwo na Równinie Wrocławskiej utrzymuje się niemal nieprzerwanie od początku neolitu do czasów współczesnych (Kulczycka-Leciejewiczowa 1993), co oznacza możliwość występowania trawiastych lub trawiasto-leśnych formacji roślinnych przez okres przynajmniej 4 tysięcy lat.

$\mathrm{W}$ osadach niedawno odkrytego niewielkiego, zamulonego torfowiska w centralnej części Równiny Wrocławskiej, wstępnie potwierdzono bezwzględną dominację dębu oraz traw z rodziny Poaceae w spektrum pyłkowym od przełomu atlantyku i subboreału (Malkiewicz i Tomaszewska - inf. ustna), co potwierdza występowanie formacji łąkowo-leśnych (lecz nie stepowo-leśnych) o charakterze lasu parkowego (wypasowego) na Równinie Wrocławskiej przez znaczną część późniejszego holocenu. $Z$ kolei pod kurhanami neolitycznymi, na wzgórzu lessowym w okolicy Henrykowa (wschodnie obrzeża Niziny Śląskiej) zidentyfikowano czarnoziemne poziomy humusowe, których wiek został wstępnie wydatowany na $4200-4600$ lat BP (Przybył - inf. ustna). Obydwa znaleziska zdaja się potwierdzać brak zwartej pokrywy leśnej i możliwość tworzenia się poziomów mollic w okresie neolitycznym na lessach Niziny Śląskiej, zarówno w obniżeniach na równinie, jak i na wzniesieniach.

Nie jest możliwe, by wyłącznie przy udziale systemów korzeniowych roślinności, szczególnie błotnej, a bez intensywnej zooturbacji powstały strukturalne mineralne poziomy próchniczne o miąższości przekraczającej $40-50 \mathrm{~cm}$ w położeniach nieotrzymujacych dostawy materiału deluwialnego lub aluwialnego (Alexandrovskiy 2007; Driessen et al. 2000). Jednocześnie, stałe nadmierne uwilgotnienie lub podtopienie gleby, eliminuje dżdżownice i ryjące ssaki glebowe lub drastycznie ogranicza ich aktywność (Alexandrovskiy 2007). Bardzo prawdopodobna jest zatem teza, że czarne ziemie (na przykład wrocławskie) powstały, przynajmniej w niektórych płatach, w efekcie procesu darniowego (czarnoziemnego), przy udziale leśno-łąkowej formacji roślinnej i dużej aktywności fauny glebowej, w warunkach umiarkowanej wilgotności podłoża. Przemawia za tym między innymi obecność nieoglejonych czarnoziemów występujących w bezpośrednim sąsiedztwie silnie oglejonych czarnych ziem, na przykład w rejonie Lagiewnik - Jordanowa Śląskiego (Musztyfaga 2013), a także brak cech glejowych w czarnoziemach pod kurhanami neolitycznymi, w rejonie Henrykowa (Kabała-mat. niepublikowane). Silnych cech glejowych, widocznych obecnie w profilach, gleby mogły nabrać w efekcie zwiększenia wilgotności klimatu w późniejszym okresie - subatlantyckim. Podobnie na niektórych wzorcowych powierzchniach Kamiennego Stepu w obwodzie woroneskim, gdzie swoje pionierskie badania prowadził Dokuczajew, Khitrov i Chewerin (2007) opisują płaty czarnoziemów z licznymi śladami aktywności ssaków ryjących, znajdującymi się obecnie w strefie silnego oglejenia. Autorzy uważaja, że taka aktywność zwierząt nie była możliwa w warunkach nadmiernego uwilgotnienia, a silne oglejenie uważają za cechę późniejszą w stosunku do czarnoziemnego poziomu próchnicznego.

Koncepcja mówiąca o przeobrażeniu umiarkowanie wilgotnych czarnoziemów leśno-łąkowych w wilgotne lub nawet mokre czarne ziemie nie jest nowa, gdyż w generalnym zarysie zgodna jest z wnioskami Musierowicza i Koneckiej-Betley (1959) dla niektórych czarnych ziem kujawskich, Uggli i Witka (1958) dla czarnych ziem kętrzyńskich, Borowca $(1960,1962)$ dla niektórych czarnych ziem pyrzyckich oraz Chojnickiego (1997) dla czarnych ziem błońsko-sochaczewskich. Możliwość „,czarnoziemowej” genezy pyłowych „szarych ziem” Dolnego Śląska dopuszczał Borkowski (1964), a w odniesieniu do czarnych ziem okolic Kłodzka - Drozd et al. (2007) oraz Labaz (2010). Wymienieni autorzy wskazują możliwość tworzenia się (niebagiennych) czarnych ziem przy udziale roślinności trawiastej, ale raczej „łąkowej” a nie „,stepowej”.

\section{Smolnice i czarne ziemie z cechami vertic}

Odrębną grupę stanowią gleby wytworzone z pęczniejących iłów lub ciężkich glin, o wybitnie czarnym 
poziomie próchnicznym, mającym zdolność do „samopogłębiania". Cechami diagnostycznymi tych gleb są: obecność poziomu vertic z powierzchniami ślizgu (,slickensides”) oraz okresowe spękania (szczeliny), sięgające niekiedy do głębokości $150 \mathrm{~cm}$. Na terenie Polski gleby takie, zwane na ogół smolnicami występują m.in. w okolicach Gniewu (Prusinkiewicz 2001), Ciechanowa (Olszewski 1956) oraz Kętrzyna i Reszla (Uggla i Witek 1958). Ich bardzo zwięzły skład granulometryczny, w którym zawartość frakcji ilastych $(<0,002 \mathrm{~mm})$ niekiedy przekracza $50 \%$ (Mocek et al. 2009) powoduje, że niezależnie od położenia przeważnie są silnie oglejone wskutek stagnowania wód opadowych i roztopowych. Smolnice były zaliczane do czarnych ziem aż do momentu realnego wdrożenia kryteriów poziomu mollic, których gleby ilaste często nie spełniają (ze względu na masywny układ agregatów w stanie suchym). W Systematyce gleb Polski (1989) smolnice nie będą zatem zaliczane do czarnych ziem, ale do nowo wyróżnionego rzędu vertisoli. Trzeba zaznaczyć, że w przypadku rozpoznania poziomu mollic w ilastej smolnicy, gleba ta według SgP (2011) nie będzie należała do vertisoli lecz do czarnych ziem, choć klasyfikacja międzynarodowa (IUSS working group WRB 2014) dopuszcza możliwość obecności poziomu mollic w ilastych vertisolach.

Oprócz gleb o ilastym uziarnieniu w całym profilu, spotyka się również czarne ziemie pyłowo-gliniaste płytko podścielone iłami, w których występuje podpowierzchniowy poziom vertic o soczewkowej strukturze i z błyszczącymi powierzchniami agregatów. Gleby te mają głęboki, czarny i strukturalny poziom mollic oraz cechy silnego oglejenia odgórnego w strefie kontaktowej oraz w poziomie vertic. Gleb tych nie można zaliczyć do smolnic/vertisoli ze względu na nieilaste uziarnienie warstw powierzchniowych, choć wykazano, że w odpowiednich warunkach wilgotnościowych i te gleby wytwarzały charakterystyczny mikrorelief gilgai, dziś niewidoczny na powierzchni ze względu na wyrównującą orkę (Przekora 2007). Niestety, SgP (2011) nie wyróżnia podtypu czarnych ziem z poziomem vertic, choć było to postulowane m.in. przez Mocka et al. (2009).

\section{PODSUMOWANIE I SUGESTIE DO SYSTEMATYKI GLEB POLSKI}

\section{Geneza i definicja czarnych ziem}

Analiza bogatego piśmiennictwa upoważnia do wyróżnienia następujących ścieżek powstawania czarnych ziem:
- czarne ziemie pojeziorne, powstałe na drodze rolniczego zagospodarowania odwodnionych osadów limnicznych, przeważnie organiczno-mineralnych lub mineralnych, z płytką powierzchniową warstwą organiczną, często węglanowych,

- czarne ziemie błotne, powstałe po odwodnieniu i zagospodarowaniu naturalnych gleb torfowo- (torfiasto-, murszowo-) glejowych wytworzonych w warunkach regularnego lub okresowego zalewania i stagnowania wód powierzchniowych,

- czarne ziemie deluwialne, powstałe przez nadbudowanie poziomu próchnicznego materiałem zmytym z terenów wyżej położonych i spowolnienie mineralizacji materii organicznej w okresowych warunkach redukcyjnych,

- czarne ziemie powstałe z czarnoziemów łąkowoleśnych wskutek późniejszego zwiększenia wilgotności profilu glebowego, zaistnienia warunków redukcyjnych i rozwoju cech glejowych,

- poligenetyczne czarne ziemie z podpowierzchniowym poziomem iluwiacji iłu, których poziom próchniczny ukształtowany został przy udziale procesu błotnego albo darniowego (czarnoziemowego) albo akumulacji materiału deluwialnego, na bazie profilu starszej gleby płowej,

- czarne ziemie ukształtowane przy udziale procesów pęcznienia i kurczenia (wertylizacji).

Czarne ziemie są młodym (subboreał) lub bardzo młodym (subatlantyk, czasy współczesne) elementem pokrywy glebowej, a ich powstanie w większości przypadków jest związane z pośrednim lub bezpośrednim wpływem człowieka.

Czarne ziemie wyróżnione zostały przez Miklaszewskiego (1930) ze względu na specyficzną genezę pobagienna, jednak wskutek stopniowego włączania do nich innych gleb o zbliżonej morfologii, ale o różnym pochodzeniu, zamieniły się w jednostkę, którą obecnie można definiować już tylko na podstawach morfologicznych. Uniwersalnymi cechami czarnych ziem są: obecność poziomu diagnostycznego mollic/ umbric oraz silne oglejenie gruntowe (oddolne) lub opadowe (odgórne), związane z okresowym lub stałym nadmiernym uwilgotnieniem spowodowanym przez każdego rodzaju wody (gruntowe, śródpokrywowe, opadowe, zalewowe itd.).

\section{Kryteria rozgraniczające czarne ziemie od innych typów gleb}

Wskutek poligenezy, w profilach czarnych ziem mogą występować poziomy lub cechy diagnostyczne dla innych typów gleb. Kluczowe jest precyzyjne rozgraniczenie poszczególnych typów gleb, jeśli systematyka faktycznie ma bazować na obiektywnych 
i rozłącznych kryteriach morfologicznych oraz fizykochemicznych. Zidentyfikowano następujące obszary problemowe, wymagające doprecyzowania w $\mathrm{SgP}$ (2011).

Intensywność oglejenia czarnoziemów. Wydaje się, że niektóre pyłowe (lessowe) czarne ziemie Polski zachodniej, morfologicznie nie różnią się od czarnoziemów opadowo-glejowych Polski wschodniej. Zatem należy jednoznacznie określić ,,próg” intensywności i głębokości oglejenia (gruntowego lub opadowego), po przekroczeniu którego gleba zaliczana jest do czarnych ziem, nawet jeśli czarnoziemna geneza poziomu próchnicznego jest bezsporna.

Czarne ziemie i mady czarnoziemne. Wiele czarnych ziem „błotnych” opisanych w polskiej literaturze gleboznawczej wyróżniono na wyższych terasach zalewowych (holoceńskich), szczególnie w rynnach dawnych starorzeczy. Pozycja tych gleb w świetle $\mathrm{SgP}$ (2011) nie jest jednoznaczna, gdyż nie dość precyzyjnie zapisano, czy o zaliczeniu do mad czarnoziemnych decyduje: (i) obecność lub brak stratyfikacji materiału aluwialnego $\mathrm{w}$ profilu glebowym, szczególnie w jego górnej części, (ii) położenie w określonej części doliny, czy (iii) występowanie zalewów powodziowych.

Czarne ziemie i gleby deluwialne. W typie gleb deluwialnych systematyka dopuszcza silne oglejenie profilu. Zatem jedyną cechą rozróżniającą czarne ziemie (szczególnie kumulacyjne) i gleby deluwialne czarnoziemne staje się stratyfikacja materiału macierzystego, wskazująca na jego deluwialny charakter. Niezbędne jest zatem sprecyzowanie minimalnej miąższości oraz morfologicznych cech materiału deluwialnego decydujących o zaliczeniu do typu gleb deluwialnych (problem dotyczy nie tylko gleb deluwialnych czarnoziemnych, ale gleb deluwialnych w ogóle).

Czarne ziemie i vertisole. Aktualna definicja vertisoli wyklucza obecność w nich poziomu mollic lub umbric, natomiast wśród czarnych ziem nie przewidziano podtypu z poziomem vertic. Zatem gleby z poziomem mollic i vertic klasyfikowane muszą być jako czarne ziemie typowe, a gleby z poziomem umbric i vertic - jako czarne ziemie wyługowane, co nie odzwierciedla istotnych cech morfologicznych i fizykochemicznych tych gleb.

Czarne ziemie i gleby murszaste. Równoległe wyróżnienie typu gleb murszastych, wytworzonych $\mathrm{z}$ tych samych materiałów macierzystych, $\mathrm{z}$ tym samym poziomem diagnostycznym (murszastym), a także z jednakową możliwością występowania węglanów w profilu powoduje, że rozróżnianie czarnych ziem murszastych i gleb murszastych typowych jest w wielu przypadkach niemożliwe w oparciu o SgP (2011).

\section{Typy oglejenia w czarnych ziemiach}

Oryginalna koncepcja czarnych ziem bagiennych, eksponowała podmokłość gleb i cechy glejowe, związane $\mathrm{z}$ wysokim zwierciadłem wody gruntowej w niecce zanikającego jeziora. Również w czarnych ziemiach genezy błotnej, oczywistą przyczyną oglejenia są wody gruntowe. Jednakże w wielu czarnych ziemiach: (i) mających dwudzielne uziarnienie (na przykład piasków naglinowych lub pyłów naiłowych), (ii) mających uziarnienie gliniasto-ilaste $\mathrm{w}$ całym profilu, albo (iii) mających trudno przepuszczalny poziom argic, może dominować stagnowanie wody opadowej w górnej części profilu oraz oglejenie odgórne (opadowe). Ponadto, niesłuszna wydaje się rezygnacja przez $\mathrm{SgP}$ (2011) z odrębnych symboli dla oglejenia gruntowego i opadowego, która powoduje, że terminologicznej odrębności podtypów gleb towarzyszy brak różnic w zapisie ich profili.

\section{Rodzaje węglanów w czarnych ziemiach}

We wzorcowych zapisach profili glebowych, $\mathrm{SgP}$ (2011) stosuje wyłącznie symbol „k” oznaczający pedogeniczną akumulację węglanów, tzw. wtórnych, podczas gdy w czarnych ziemiach genezy pojeziornej występują węglany pochodzące $\mathrm{z}$ sedymentacji „pierwotnej” na dnie zbiornika (niekiedy w formie gytii węglanowej lub kredy jeziornej).

\section{Poziom anthric w czarnych ziemiach}

Przynajmniej w połowie profili glebowych, przeanalizowanych na potrzeby niniejszego opracowania (w niektórych pracach -w 100\%) poziom orno-próchniczny ostro odcina się od reszty profilu glebowego. Fotografie dołączone do niektórych opracowań jednoznacznie dokumentują ślad lemiesza lub głębosza potwierdzając, że miąższe poziomy próchniczne wielu czarnych ziem zostały uformowane w wyniku orki (m.in. Marcinek i Komisarek 2004; Meller 2006). W tym kontekście zaskakuje fakt, że SgP (2011) nie uwidacznia poziomu anthric w czarnych ziemiach, choć w znacznej części czarnych ziem typowych i glejowych (a także niektórych murszastych) spełnione są kryteria poziomu anthric. Wyróżnianie czarnych ziem $\mathrm{z}$ poziomem anthric (w formie podtypu lub odmiany różnych podtypów) byłoby użytecznym narzędziem służącym podkreśleniu naturalnej genezy poziomów próchnicznych niektórych czarnych ziem (Prusinkiewicz i Kowalkowski 1964) lub odwrotnie - uznaniu roli i skali udziału człowieka w powstaniu czarnych ziem na danym terenie (Marcinek i Komisarek 2004). 


\section{LITERATURA}

Albrecht C., Kühn P., 2011. Properties and formation of black soils on the Island of Poel (NE Germany). Quaternary International 243(2): 305-312.

Alexandrovskiy A.L., 2007. Rates of soil-forming processes in three main models of pedogenesis. Revista Mexicana de Ciencias Geológicas 24(2): 283-292.

Altermann M., Rinklebe J., Merbach I., Körschens M., Langer U., Hofmann B., 2005. Chernozem - soil of the year 2005. Journal of Plant Nutrition and Soil Sciences 168: 725-740.

Bakker E.S., Olff H., Vandenberghe C., De Maeyer K., Smit R., Gleichman J.M., Vera F.W., 2004. Ecological anachronism in the recruitment of temperate light-demanding tree species in wooded pastures. Journal of Applied Ecology 41: 571-582.

Bogacz A., Łabaz B., Dąbrowski P., 2008. Wybrane właściwości fizyczne i fizykochemiczne czarnych ziem w Parku Krajobrazowym Dolina Baryczy. Roczniki Gleboznawcze - Soil Science Annual 59(1): 43-51.

Borek S., 1975. Kierunki zmian właściwości czarnych ziem błonsko-sochaczewskich po drenowaniu. Roczniki Gleboznawcze - Soil Science Annual 26(1): 101-140.

Borkowski J., 1964. Czarne i szare ziemie wytworzone z utworów pyłowych i pylastych na obszarze Śląska. Roczniki Gleboznawcze - Soil Science Annual 14(1): 61-78.

Borowiec J., 1965. Czarnoziemy Wyżyny Lubelskiej. Cz. I. Warunki występowania i ogólna charakterystyka gleb. Annales UMCS, seria E: 1-19.

Borowiec J., Urban D., Mikosz A.I., 2007. Zmienność geochemiczna siedlisk łąkowych doliny Bugu w rejonie Dubienki. Annales UMCS, seria E 62(2): 205-216.

Borowiec S., 1960. Zagadnienie genezy gleb wytworzonych $\mathrm{z}$ utworów pyrzyckiego plejstoceńskiego zastoiska wodnego w świetle dotychczasowych badań. Zeszyty Naukowe WSR w Szczecinie 4: 17-37.

Borowiec S., 1961. Warunki przyrodnicze i geneza gleb plejstoceńskiego zastoiska wodnego. Przegląd Geograficzny 33(1): 83-92.

Borowiec S., 1962. O występowaniu reliktowych czarnoziemów na terenie województwa szczecińskiego. Przegląd Geograficzny 34(4): 739-747.

Chojnicki J., 1994. Czarne ziemie Równiny Błońsko-Sochaczewskiej wytworzone z pokrywowych utworów pyłowych. Roczniki Gleboznawcze - Soil Science Annual 45(3/4): 97-107.

Chojnicki J., 1997. Ewolucja gleb wytworzonych z pokrywowych utworów pyłowych Równiny Błońsko-Sochaczewskiej. Roczniki Gleboznawcze - Soil Science Annual,48(1/2): 79-86.

Cierniewski J., 1986. Zmienność przestrzenna czarnych ziem właściwych wycinka Równiny Kościańskiej określona na podstawie badań przekrojów glebowych. Roczniki Gleboznawcze - Soil Science Annual 38(4): 95-111.

Cieśla W., 1961. Właściwości chemiczne czarnych ziem kujawskich. Poznańskie Tow. Przyj. Nauk., Prace Komisji Nauk Rolniczych i Komisji Nauk Leśnych 8(4): 4-89.

Cieśla W., 1968. Geneza i właściwości gleb uprawnych, wytworzonych z gliny zwałowej na Wysoczyźnie Kujawskiej. Rocz. WSR Poznań. Prace habilitacyjne 18: 60 pp.

Czerepko J., 2010. Zmiany roślinności na siedlisku olsu jesionowego w lasach północno-wschodniej Polski. Forest Research Papers 71(4): 331-342.
Dobrzański B., Zbysław B., 1955. Czarnoziemy na lessach Przedkarpacia. Ann. UMCS, seria E 10(9): 287-299.

Dreibrodt S., Jarecki H., Lubos C., Khamnueva S.V., Klamm M., Bork H.-R., 2007. Holocene soil formation and soil erosion at a slope beneath the Neolithic earthwork Salzmünde (Saxony-Anhalt, Germany). Catena 107: 1-14.

Driessen P., Deckers J., Spaargaren O., Nachtergaele F., 2000. Lecture notes on the major soils of the world. FAO Reports 94. Rome: $334 \mathrm{pp}$.

Drozd J., Piątek J., Łabaz B., 2007. Właściwości gleb czarnoziemnych występujących w rejonie Kłodzka. Zeszyty Problemowe Postępów Nauk Rolniczych 520(2): 447-454.

Drzymała S., 1974. Geneza i właściwości gleb uprawnych „typu krotoszyńskiego“. Akademia Rolnicza, Instytut Gleboznawstwa i Chemii Rolnej, Poznań, rozprawa doktorska, maszynopis: 103 pp.

Eckmeier E., Gerlach R., Gehrt E., Schmidt M.W.I., 2007. Pedogenesis of Chernozems in central Europe - A review. Geoderma 139: 288-299.

Firbas F., 1949. Über das Verhalten von Artemisia in einigen Pollendiagrammen. Biologische Zentralblatt 67: 17-21.

Gonet S., Markiewicz M., Marszelewski W., Dziamski A., 2010. Soil transformations in catchment of disappearing Sumówko Lake (Brodnickie Lake District, Poland). Limnological Review 10(3-4): 133-137.

IUSS Working Group WRB, 2014. World Reference Base for Soil Resources 2014. International soil classification system for naming soils creating legends for soil maps. World Soil Resources Reports 106. FAO Rome: 181 pp.

Jary Z., Ciszek D3. Late Pleistocene loess-palaeosol sequences in Poland and western Ukraine. Quaternary International 296: $37-50$.

Kabała C., Gałka B., Jezierski P., Bogacz A., 2011. Transformacja mad w warunkach regulacji rzeki i długotrwałego użytkowania rolniczego w dolinie Dobrej na Nizinie Śląskiej. Roczniki Gleboznawcze - Soil Science Annual 62(2): 141-153.

Khitrov N.B., Chewerdin Y.I., 2007. Rasprostranene sezonno pereuwlashennych i zatoplennych pochv w Kamennoi Stepi. [In:] Kamennaya Step': problemy izucheniya pochvennogo pokrova (Khitrov N.B., Editor). GNU PI RSHA, Moskva: 121-133.

Klimowicz Z., 1980. Czarne ziemie Równiny Tarnobrzeskiej na tle zmian stosunków wodnych gleb tego obszaru. Roczniki Gleboznawcze - Soil Science Annual 31(1): 163-206.

Komisarek J., 1994. Zmienność przestrzenna czarnych ziem i gleb płowych falistej moreny dennej Równiny Kościańskiej. Roczniki AR Poznań, 168: 203-217.

Komisarek J., 2000. Kształtowanie się właściwości gleb płowych i czarnych ziem oraz chemizmu wód gruntowych w katenie falistej moreny dennej Pojezierza Poznańskiego. Roczniki AR Poznań. Rozprawy Naukowe 307: 143 pp.

Konecka-Betley K., 2013. Gleby kopalne jako jednostki klasyfikacji stratygraficznej czwartorzędu. Geological Quarterly 31(1): 185-190.

Konecka-Betley K., Czępińska-Kamińska D., Janowska E., 1996. Czarne ziemie w staroaluwialnym krajobrazie Puszczy Kampinoskiej. Roczniki Gleboznawcze - Soil Science Annual 47(3-4): 145-158.

Kowaliński S., 1952. Czarne ziemie wrocławskie (ich własności, wartość użytkowo-rolnicza i geneza). Roczniki Gleboznawcze - Soil Science Annual 2: 59-91. 
Kowalkowski A., 1966. Główne kierunki rozwoju gleb w warunkach środowiska morfogenetycznego Wzgórz Dalkowskich. Roczniki Gleboznawcze - Soil Science Annual 16(2): 357-411.

Kozłowski M., Komisarek J., 2013. Niedobory wody łatwo dostępnej dla roślin w czarnej ziemi z poziomem cambic. Nauka Przyroda Technologie 7(4): 1-14.

Krysiak S., Tołoczko W., 2004. Zróżnicowanie krajobrazowe terenów nadpilicznych w okolicach Wielkopola. Acta Universitatis Lodzensis, Folia Geographica Physica 6: 71-90.

Kulczycka-Leciejewiczowa A., 1993. Osadnictwo neolityczne w Polsce południowo-zachodniej - próba zarysu organizacji przestrzennej. Inst. Archeologii i Enologii PAN, Wrocław: 223 pp.

Lemkowska B., Sowiński P., 2008. Ewolucja rędzin pojeziornych w krajobrazie Pojezierza Mazurskiego. Roczniki Gleboznawcze - Soil Science Annual 59(1): 134-140.

Łabaz B., 2010. Właściwości kwasów huminowych gleb czarnoziemnych występujących w rejonie Kłodzka. Woda-Środowisko-Obszary Wiejskie 10: 153-164.

Labaz B., Bogacz A., Glina B., 2011. Humus substances of forest Phaeozems and Gleysols in Dolina Baryczy Landscape Park. Polish Journal of Soil Science,44(1): 51-62.

Malinowska E., Ceglińska K., 2011. Przestrzenna zmienność właściwości gleb w układach katenalnych w rejonie Murzynowa. Prace i Studia Geograficzne 46: 77-92.

Malinowski R., Niedźwiecki E., Meller E., Kubus M., Podlasiński M., 2013. Przydatność gleb porolnych przeznaczonych pod powiększenie kolekcji Ogrodu Dendrologicznego w Przelewicach. Folia Pomerania Universitatis Tech. Stetinensis 305(27): 35-50.

Marcinek J., Komisarek J., 2004. Antropogeniczne przekształcenia gleb Pojezierza Poznańskiego na skutek intensywnego użytkowania rolniczego. Wyd. AR Poznań: 118 pp.

Marcinek J., Wiślańska A., 1984. Asocjacje czarnych ziem i gleb płowych falistej moreny dennej Równy Kościańskiej. Roczniki AR, Poznań 149: 65-79.

Meller E., 2006. Płytkie gleby organogeniczno-węglanowe na kredzie jeziornej i ich przeobrażenia w wyniku uprawy. Wyd. AR, Szczecin, Rozprawy 233: 115 pp.

Meller E., Sienkiewicz M., Niedźwiecki E., Gołębiowska D., 2009. Parametry związków próchnicznych gleb pobagiennych wytworzonych na kredzie jeziornej jako wskaźniki ich przynależności systematycznej. Roczniki Gleboznawcze - Soil Science Annual 60(3): 114-122.

Mendyk Ł., Markiewicz M., 2013. Wpływ stopnia odwodnienia na właściwości gleb wytworzonych z osadów jeziornych. Episteme 18(3): 321-327.

Michałek K., 1971. Czarne ziemie Równiny Kaliskiej. Maszynopis: $41 \mathrm{pp}$.

Mieczyński T., 1947. Gleby i wytwórczość Pomorza Zachodniego. Wydawnictwo Instytutu Bałtyckiego: 40 pp.

Miklaszewski S., 1930. Gleby Polski. Warszawa: 638 pp.

Mocek A., Owczarzak W., Tabaczyński R., 2009. Uziarnienie oraz skład mineralogiczny frakcji ilastej czarnych ziem Gniewskich. Roczniki Gleboznawcze - Soil Science Annual 60(3): 123-132.

Musierowicz A., 1953. Gleboznawstwo szczegółowe. PWRiL, Warszawa: $288 \mathrm{pp}$.

Musierowicz A., 1959. Zarys systematyki gleb Polski. Z zagadnień ustalenia systematyki gleb. Zeszyty Problemowe Postępów Nauk Rolniczych 16: 3-277.

MusierowiczA., Konecka-Betley K., 1959. Studia nad kompleksem sorpcyjnym i zawartością kationów wymiennych w waż- niejszych glebach województwa łódzkiego. Roczniki Gleboznawcze - Soil Science Annual 8: 167-215.

Musierowicz A., Olszewski Z., Brogowski M., Kępka M., 1961. Czarne ziemie błońsko-sochaczewsko-łowickie. Roczniki Nauk Rolniczych 82-A-3: 503-559.

Musierowicz A., Olszewski Z., Kuźnicki F., Święcicki C., Konecka-Betley K., Leszczyńska E., 1956. Gleby województwa warszawskiego. Roczniki Nauk Rolniczych 75-D: 5-238.

Musztyfaga E., 2013. Właściwości fizyczne i fizykochemiczne gleb czarnoziemnych i płowoziemnych na obszarze Równiny Wrocławskiej. Uniwersytet Przyrodniczy we Wrocławiu, praca magisterska, maszynopis: $122 \mathrm{pp}$.

Olszewski Z., 1956. Ciężkie gleby ciechanowskie. Roczniki Nauk Rolniczych 75-D: 239-316.

Olszewski Z., Sikorska K., Barański E., 1962. Czarne ziemie kujawskie. Roczniki Nauk Rolniczych 97-D: 5-86.

Patalan I., Rączka G., Strzeliński P., Sugiero D., Węgiel A., 2007. Zróżnicowanie siedlisk leśnych w rezerwacie przyrody Żądłowice. Studia i Mat. Centrum Edukacji Przyrodniczo-Leśnej 9(2-3 (16) cz. 1).

Prusinkiewicz Z., 2001. Smolnice gniewskie. Właściwości, geneza, systematyka. Roczniki Gleboznawcze - Soil Science Annual 52(1/2): 5-21.

Prusinkiewicz Z., Kowalkowski A., 1964. Studia gleboznawcze w Białowieskim Parku Narodowym. Roczniki Gleboznawcze - Soil Science Annual 14(2): 161-306.

Przekora A., 2007. Charakterystyka i geneza nieckowatych form morfologicznych w profilach czarnych ziem w Tyńcu na Równinie Wrocławskiej. Uniwersytet Przyrodniczy we Wrocławiu. Praca magisterska, maszynopis: 88 pp.

Przyrodniczo-genetyczna klasyfikacja gleb Polski. 1956. Roczniki Nauk Rolniczych 74: 10-96.

Rozporządzenie Rady Ministrów z dnia 8 stycznia 1957 r. w sprawie gleboznawczej klasyfikacji gruntów. Dz.U. nr 5 poz. 21.

Stasik R., Szafrański C., 2005. Zmiany w pokrywie glebowej erodowanych terenów Pojezierza Gnieźnieńskiego. Acta Agrophysica 5(2): 447-454.

Staszewski T., 1967. Właściwości chemiczne i fizyczne czarnych ziem Zastoiska Szamotulskiego jako podstawy produkcji ogrodniczej. Wyższa Szkoła Rolnicza, Katedra Uprawy i Nawożenia Roli, rozprawa doktorska, maszynopis: 89 pp.

Stremme H., 1930. Die Boden Deutschlands. [W: ] Blanck E. (red.) Handbuch der Bodenlehre. Band 5. Springer, Berlin: 271-426.

Strzemski M., 1954. „Czarne ziemie” jako wskaźnik odwodnienia kraju. Gospodarka Wodna 2: 1-46.

Strzemski M., 1961. Przemiany środowiska geograficznego Polski, jako tha przyrodniczego rozwoju rolnictwa na ziemiach polskich: od połowy trzeciego tysiąclecia p.n.e. do naszych czasów. Kwartalnik Historii Kultury Materialnej 9(3): 331-357.

Strzemski M., Siuta J., Witek T., 1973. Przydatność rolnicza gleb Polski, PWRiL, Warszawa: 352 pp.

Systematyka gleb Polski, 1974. Roczniki Gleboznawcze - Soil Science Annual 25(1): 1-148.

Systematyka gleb Polski, 1989. Roczniki Gleboznawcze - Soil Science Annual 40(3/4): 1-150.

Systematyka gleb Polski, 2011. Roczniki Gleboznawcze - Soil Science Annual 62(3): 1-193.

Szafer W., 1959. Szata roślinna Polski. PWN, Warszawa: 586 pp.

Tomaszewski J., 1954. Uwagi krytyczne odnośnie systematyki gleb Polski. Roczniki Gleboznawcze - Soil Science Annual 3: 106-116. 
Tomaszewski J., 1956. Gleby błotne i środowisko. Roczniki Gleboznawcze - Soil Science Annual 5: 73-99.

Turski R., 1980. Czarnoziem Polski. Materiały z Konf. Nauk. Komisji V PTG, Jabłonna.

Uggla H., 1957. Niektóre gleby województwa olsztyńskiego w świetle konferencji terenowej Polskiego Towarzystwa Gleboznawczego. Roczniki Gleboznawcze - Soil Science Annual 6: $288-244$.

Uggla H., Witek T., 1958. Czarne ziemie kętrzyńskie. Zesz. Nauk. WSR Olsztyn 3: 69-108.
Uziak S., Bogda A., Chodak T., Cieśla W., Komornicki T., Stoch L., Wilgat M. 1987. Clay minerals of selected loess soils. Roczniki Gleboznawcze - Soil Science Annual 38(3): 59-77.

Uziak S., Poznyak S. P., Wyszniewskij J., 2010. Gleby Roztocza. Ann. UMCS, Geographia, Geologia, Mineralogia et Petrographia 65(1): 99-115.

Wierszyłowski J., Kotar S., 1947. Wyniki badań gleboznawczych w sadach powiatów Błonie i Sochaczew. Przegląd Doświadczalnictwa Rolnego 3: 174-189.

Received: April 16, 2014

Accepted: September 1, 2014

\title{
Origin, properties and classification of "black earths" in Poland
}

\begin{abstract}
Black earths as an independent unit in soil classification were distinguished from chernozems by Miklaszewski due to their post-swamp origin, wetness and a specific type of ,acid” humus. During following decades, other wet (gleyed) soils with thick humus horizon were included; however, originated in different ways: (1) black earths on lake sediments, (2) black earths developed from Histic Gleysols, (3) colluvial black earths, (4) black earths with vertic horizon, (5) secondary re-wetted meadow-forest chernozems, (6) polygenetic black earths with subsurface clay accumulation. Classification of soils with such variable origins must be based on common morphological criteria that is in accordance with the trend set by two last Polish soil taxonomies (1989 and 2011). However, an affiliation to black earths it is not always evident, due to the vague delimitation from related soils, including chernozems (intensity of stagnic properties), alluvial and colluvial soils (stratification of the parent material and/or the mollic horizon), vertisols (attendance of the mollic and vertic horizons), and "murshic" soil (no differences in diagnostic criteria). Furthermore, discussion and improvement is required in the characteristic of black earths in the following subjects: nature of redoximorphic features (stagnic and gleyic properties), the type of carbonates (primary and secondary), and the presence of anthric diagnostic horizon.
\end{abstract}

Keywords: black earths, Chernozems, alluvial soils, colluvial soils, Vertisols 